\title{
Investors' reactions to companies' stakeholder management: the crucial role of assumed costs and perceived sustainability
}

\author{
Tanja Schwarzmüller ${ }^{1} \cdot$ Prisca Brosi $^{1}$. \\ Vera Stelkens $^{2} \cdot$ Matthias Spörrle $^{3} \cdot$ Isabell M. Welpe $e^{1,4}$
}

Received: 31 December 2015/Accepted: 18 November 2016/Published online: 25 November 2016

(C) The Author(s) 2016. This article is published with open access at Springerlink.com

\begin{abstract}
Companies regularly have to address opposing interests from their shareholding and non-shareholding stakeholder groups. Consequently, a wealth of previous research has focused on how CEOs decide which stakeholder management activities to pursue and prioritize. In contrast, however, surprisingly little research has considered how (potential) investors react to a company's management of shareholding and non-shareholding stakeholders and what factors drive their reactions in such contexts. We seek to fill this gap in the literature by conducting an experimental scenario study $(N=997)$ in which investment behavior is analyzed in situations in which management has to make a trade-off between shareholders' and non-shareholding stakeholders' interests. Our results show that (potential) investors consider the assumed costs of fulfilling non-shareholding stakeholders' interests and the perceived sustainability of doing so for corporate success when making investment decisions in such contexts. In cases of low costs or high sustainability, participants were more willing to invest in a company that favored nonshareholding over shareholding stakeholders (thereby deciding against their immediate financial interests), while the opposite was true in cases of high costs or low sustainability. With these results, our paper broadens stakeholder theory's focus by taking individual investors' reactions to corporate stakeholder management into account. Moreover, it both provides evidence for and extends the "Enlightened
\end{abstract}

Tanja Schwarzmüller

t.schwarzmueller@tum.de

1 Chair for Strategy and Organization, TUM School of Management, Technical University of Munich, Arcisstraße 21, 80333 Munich, Germany

2 Konzernbereich Konzernentwicklung, Strategisches Nachhaltigkeitsmanagement, Flughafen München GmbH, Postfach 2317 55, 85326 Munich-Flughafen, Germany

3 Private University Seeburg Castle, Seeburgstraße 8, 5201 Seekirchen am Wallersee, Austria

4 Bavarian State Institute for Higher Education Research and Planning, Prinzregentenstraße 24, 80538 Munich, Germany 
Stakeholder Theory", which proposes that organizations should fulfill stakeholders' interests if doing so contributes to long-term firm value enhancement, but has so far not considered the role of the costs necessary for fulfilling stakeholders' claims in such decisions.

Keywords Stakeholder management · (Potential) investors · Investment decisions $\cdot$ Financial sustainability $\cdot$ Costs $\cdot$ Enlightened stakeholder theory

\section{Introduction}

It has frequently been acknowledged that organizations need to constantly weigh the needs of different stakeholders (i.e., those groups that are affected by or that can affect their objectives and actions; Freeman 1984; Laplume et al. 2008). In particular, conflicts can arise between shareholding stakeholders and non-shareholding ones, such as customers, suppliers, employees, and the communities in which organizations operate (Donaldson and Preston 1995). Trying to solve these conflicts, competing theoretical perspectives have emerged. On the one hand, neoclassicists have claimed that companies should focus on enhancing returns for their shareholding stakeholders without giving too much consideration to the concerns of non-shareholding stakeholders (Friedman 1970). On the other hand, stakeholder theorists (Freeman 1984; Jones and Felps 2013) have argued that organizations should take into account the interests of all their stakeholders, including both shareholding and non-shareholding ones.

Against this background, a wealth of research has dealt with the question of how CEOs handle stakeholder dilemmas and according to which factors they decide which stakeholders' claims to fulfill (e.g., Adams et al. 2011; Mitchell et al. 1997). However, there is a decisive research gap regarding the question of how (potential) investors react to corporate stakeholder management activities (Hillenbrand et al. 2013). Although companies regularly need to make trade-offs between the interests of shareholding and non-shareholding stakeholders (Clarkson 1995; Mitchell et al. 2015), it remains unknown how (potential) investors evaluate companies' decisions in favor of one group or the other. In addition, it is currently unclear which specific factors influence individual investors' reactions to stakeholder-related decisions (Aguinis and Glavas 2012).

Based on theoretical considerations (Crane et al. 2015; Jansson and Biel 2011; Rivoli 1995), we postulate that two factors should play an important role in this relationship. First, the assumed costs for fulfilling non-shareholding stakeholders' interests should impact potential investors, as these costs affect shareholders' immediate returns (Stevens et al. 2015). Second, the perceived sustainability of fulfilling stakeholders' interests for companies' future success should also influence investors' reactions, as sustainability affects shareholders' wealth maximization in the long run (Jansson and Biel 2011; Wärneryd 2001).

Knowing how (potential) investors react to stakeholder management is important because, according to stakeholder theory (Freeman 1984), managers need to 
effectively balance the interests of all of their stakeholders. Because potential future investors will use their knowledge about a company's stakeholder management activities to decide whether and how much to invest in the company (Clark-Murphy and Soutar 2005; Schijven and Hitt 2012), their reactions can exert a crucial influence on an organization's future market capitalization. Hence, being able to anticipate investors' reactions when making trade-offs between shareholding and non-shareholding stakeholders is critical for organizations.

In sum, by analyzing (potential) investors' investment intentions in situations in which companies need to make a trade-off between shareholding and nonshareholding stakeholders, our paper makes several important theoretical contributions. First, while stakeholder theory asks managers to effectively balance the interests of different stakeholders, it "has been hampered by almost exclusive analysis of stakeholders from the perspective of the organization" (Friedman and Miles 2002, p. 2) - that is, from a managerial point of view. By focusing on (potential) investors' reactions, our paper therefore contributes to developing a more inclusive stakeholder theory. Second, by outlining the importance of assumed costs and perceived sustainability as critical moderating mechanisms, it reconciles opposing theoretical perspectives (Jansson and Biel 2011; Rivoli 1995) with regard to (potential) investors' preference for companies that prioritize either shareholding or non-shareholding stakeholders. Third, this paper enhances our current understanding of the specific factors that predict investors' judgment of stakeholder management activities (Aguinis and Glavas 2012; Hillenbrand et al. 2013), thereby contributing to our knowledge about individual investment behavior (Schijven and Hitt 2012).

From a practical point of view, the results of our study help companies to identify factors that need to be addressed to align shareholders' interests with those of nonshareholding stakeholders (Freeman et al. 2010). Thereby, they allow for adapting corporate stakeholder management and its accompanying public communication in a way that will be seen as attractive for (potential) investors-a process that has been characterized as central to companies' success (Hall et al. 2015; McWilliams and Siegel 2001; Unruh et al. 2016).

\section{2 (Potential) investors' reactions to the management of non- shareholding and shareholding stakeholders}

We propose that there is no direct answer to the controversial question of whether (potential) investors punish or reward companies for deciding in favor of nonshareholding stakeholders (Benson and Davidson 2010; Coombs and Gilley 2005). From a wealth maximization perspective (Friedman 1970; Rivoli 1995), (potential) investors may reduce their investments in response to management's prioritization of non-shareholding stakeholders due to the costs associated with it (Ogden and Watson 1999). In contrast, and in line with a sustainability perspective (Jansson and Biel 2011), (potential) investors may increase their investments in response to companies' prioritization of non-shareholding stakeholders because such prioritization is expected to sustainably increase a company's future success. 
We propose that these seemingly inconsistent theoretical perspectives might be reconciled by taking the underlying dimensions (i.e., assumed costs and perceived sustainability) into account as moderators. Thus, we assume that (potential) investors' investment intentions in response to companies' prioritization of either shareholding or non-shareholding stakeholders will depend on the assumed costs and the perceived sustainability associated with fulfilling non-shareholding stakeholders' interests. This reasoning is in line with current theoretical approaches suggesting that managers judge stakeholder management against the background of a financial time perspective, considering both short-term expenses and long-term returns in their decision-making (Crane et al. 2015).

\subsection{The moderating role of assumed costs for (potential) investors' investment intentions}

Indicating the moderating influence of assumed costs, the neoclassical paradigm (Friedman 1970) has characterized investors as driven primarily by wealth maximization concerns (Rivoli 1995). Thus, financial variables such as expected earnings are important precursors of individuals' investment behavior (Nagy and Obenberger 1994). Moreover, it has often been argued that investors behave in a purely rational and selfish manner while making investment decisions (Michelson et al. 2004). With the costs of stakeholder management lowering returns for investors (Garcia-Castro et al. 2010; Stevens et al. 2015), potential investors should thus value decisions in favor of shareholding (vs. non-shareholding) stakeholders when the costs of fulfilling non-shareholding stakeholders' interests are assumed to be high. In contrast, when the costs of fulfilling non-shareholding stakeholders' interests are seen as low, doing so might be seen as imperative, because good relations with non-shareholding stakeholders ultimately pay out in benefiting shareholders (Faleye and Trahan 2011; Hillman and Keim 2001). In consequence, (potential) investors should prefer decisions in favor of non-shareholding stakeholders (as compared to shareholding stakeholders) when the costs of fulfilling nonshareholding stakeholders' interests are seen as low.

H1 The assumed costs of managing non-shareholding stakeholders' interests will moderate the relationship between stakeholder management and (potential) investors' investment intentions, such that for high costs, investment intentions will be higher when companies prefer shareholding stakeholders, whereas for low costs, they will be higher when companies prefer non-shareholding stakeholders.

\subsection{The moderating role of perceived sustainability for (potential) investors' investment intentions}

In addition to the costs expected to result from fulfilling non-shareholding stakeholders' interests, the perceived sustainability of doing so for a company's future success is also likely to moderate the relationship between stakeholder management and investment intentions (Crane et al. 2015). Because investors pursue long-term financial goals with their investments (Jansson and Biel 2011; 
Wärneryd 2001), they should be interested in the degree to which catering to nonshareholding stakeholders' interests can sustainably increase companies' future success. This interest is reflected by the growing rates of investors making socially responsible investments (Pasewark and Riley 2010; Peifer 2014). Accordingly, when the perceived sustainability of fulfilling non-shareholding stakeholders' interests for corporate success is high, investment intentions should be higher when companies prefer the interests of non-shareholding stakeholders over those of shareholding ones. Conversely, when perceived sustainability is low, investors might perceive catering to non-shareholding stakeholders' interests as not worth the effort or even harmful to their own interests, thus leading to higher investment intentions when companies prefer shareholding over non-shareholding stakeholders in these situations.

H2 The perceived sustainability of managing non-shareholding stakeholders' interests will moderate the relationship between stakeholder management and (potential) investors' investment intentions, such that for high sustainability, investment intentions will be higher when companies prefer non-shareholding stakeholders, whereas for low sustainability, they will be higher when companies prefer shareholding stakeholders.

\section{Method}

We used a within-subject experimental scenario design to test our hypotheses, as this methodology both allows for making conclusions about causal relationships and ensures a high degree of external validity (Aguinis and Bradley 2014). Each participant received a total of four company scenarios, in which an international airport operator was confronted with the claims of its non-shareholding stakeholders. In each scenario, participants were confronted with one specific stakeholder group (e.g., airline customers). To enhance generalizability, participants were randomly assigned to one of two different claims for this stakeholder group, e.g., airline customers demanding either a reduction of airport fees or more personnel in the realm of ground services.

In line with our overall research question, these claims were depicted as representing a conflict between non-shareholding stakeholders' interests (fulfillment of their claim) and shareholding stakeholders' interests (dividend payment). Participants were then randomly assigned to one of two experimental conditions, i.e., the airport operator either fulfilling stakeholders' claims (thereby favoring nonshareholding stakeholders) or not fulfilling stakeholders' claims (thereby favoring shareholders). For example, participants assigned to airline customers' claim to reduce airport fees were either informed that the airport operator decided to fulfill the airline customers' claim by reducing airport fees (favoring non-shareholding stakeholders) or to deny the airline customers' claim by not reducing airport fees (favoring shareholders).

After each scenario, participants rated the assumed costs and the perceived sustainability of fulfilling the respective stakeholder claims and indicated their 
willingness to invest, as well as the amount they would invest, in the company. Data were collected online.

\subsection{Participants}

Overall, 997 private investors took part in our study. To enhance the generalizability of our findings, they were sampled to be representative of investors in Germany with regard to age, sex, and monthly net household income (Statista 2015). Participants were, on average, 51.31 years old $(S D=13.23)$, and $62.60 \%$ of them were male. After taxes, $14.90 \%$ earned less than $2000 €$ per month, $51.70 \%$ earned between 2000 and $4000 €$, and $33.30 \%$ earned more than $4000 €$. The majority $(57.50 \%)$ of the participants had invested less than $30,000 €$, while $10.40 \%$ had invested more than $100,000 €$.

\subsection{Scenarios}

Scenarios were derived in cooperation with an international airport operator and revolved around its core non-shareholding stakeholders (airline customers, employees, surrounding communities, and passengers). Each scenario began with a short description of the specific stakeholder group, after which non-shareholding stakeholders' claims were stated. The claims represented realistic, but hypothetical demands for the airport operator.

Scenario 1 dealt with the airport operator's airline customers, who demanded either (1) a reduction of airport fees or (2) more personnel in the realm of ground services. Scenario 2 depicted the airport operator's employees, who demanded either (1) more financial discounts for cafeterias, airport shopping, and booking holidays, or (2) more training and education offers. Scenario 3 dealt with the communities close to the airport, which demanded (1) an extended nighttime ban of aircraft or (2) a stronger co-financing of local infrastructure development projects. Scenario 4 revolved around the airport operator's passengers, who demanded (1) lower parking fees or (2) the recruitment of more security personnel to speed up security checks.

\subsection{Independent variable: manipulation of stakeholder management}

As outlined above, each of the scenarios depicted a conflict between shareholding and non-shareholding stakeholders' interests. To manipulate stakeholder management, this conflict was resolved by the airport operator deciding either in favor of shareholding stakeholders (by not fulfilling non-shareholding stakeholders' claims and thereby prioritizing a dividend payment for shareholders over non-shareholding stakeholders' interests) or in favor of non-shareholding stakeholders (by fulfilling non-shareholding stakeholders' claims and thereby prioritizing non-shareholding stakeholders' interests over a dividend payment for shareholders). In scenario 1, a decision in favor of non-shareholding stakeholders (i.e., the airport operator's airline customers) would for example be phrased as follows: "The airport operator decides to fulfill the airline customers' request, i.e., to clearly reduce airport fees, and 
thereby prioritizes the airline customers' interests over a dividend payment for shareholders".

\subsection{Dependent variable: investment intentions}

After each scenario was presented, we measured participants' investment intentions in the company by means of two constructs: First, we measured their willingness to invest in the airport operator based on their answers to the question, "How likely is it that you would buy shares of the airport operator immediately after this decision?" (MacGregor et al. 2000). Participants indicated their willingness to invest on a scale from 1 (not likely at all) to 7 (very likely). Following Weber et al. (2002), we also assessed the amount of money that participants would invest in the company with the question, "Please assume that you would be willing to invest up to $1000 €$ in shares. How much would you invest in shares of the airport operator immediately after this decision?" The scale ranged from $0 €$ to $1000 €$. The correlation between the two dependent variables was $r=0.73, p<0.001$, across scenarios.

\subsection{Moderating variables: assumed costs and perceived sustainability}

Participants judged the assumed costs for fulfilling non-shareholding stakeholders' claims by answering the question, "How cost-intensive would you guess it is for the airport operator to fulfill this claim?" on a scale from 1 (not at all) to 7 (very much). The perceived sustainability of fulfilling non-shareholding stakeholders' claims was assessed with the question, "To what degree do you think that fulfilling this claim sustainably enhances the airport operator's corporate success?" on a scale from 1 (not at all) to 7 (very much).

\subsection{Control variables}

As we conducted aggregate analyses across all scenarios to test our hypotheses, we controlled for the influence of the specific stakeholder groups with which participants were presented. Moreover, previous research has demonstrated that managers take into account stakeholders' power to influence the company, as well as the legitimacy (i.e., the degree to which a stakeholder has a legal or moral right for making a claim) and urgency (i.e., the degree to which a stakeholder's claim demands instantaneous response) of their claims when deciding whether to favor shareholding or non-shareholding stakeholders (Mitchell et al. 1997; Parent and Deephouse 2007). As these stakeholder attributes might also play a role in (potential) investors' investment intentions, we controlled for these perceived attributes in our analyses. Power $\left(M_{\alpha}=0.93\right)$, legitimacy $\left(M_{\alpha}=0.84\right)$ and urgency $\left(M_{\alpha}=0.79\right)$ were each measured with three items by Agle et al. (1999) on a scale from 1 (not at all) to 7 (very much). 


\subsection{Manipulation check}

To check whether the participants understood the experimental manipulation, after each scenario we asked them whether the airport operator's decision was in favor of the shareholding or non-shareholding stakeholders (forced choice). All participants answered these manipulation checks correctly.

\section{Results}

\subsection{Analytical strategy}

To test our hypotheses, we conducted aggregated analyses across all scenarios, applying regression analysis with clustered robust standard errors in STATA. Clustered robust standard errors account for within-subject variance resulting from each participant judging four scenarios, thereby providing unbiased estimates (Cameron and Miller 2011). The four stakeholder groups with which participants were presented in the different scenarios served as controls and were modeled by three dummy variables. ${ }^{1}$ The company's stakeholder management $(1=$ favoring non-shareholding stakeholders; $0=$ favoring shareholders) was also dummy-coded, so that the positive effects of this variable imply higher investment intentions when companies favor non-shareholding stakeholders, while negative effects imply higher investment intentions when companies favor shareholding stakeholders. The hypotheses were tested by calculating the interaction effects between stakeholder management and assumed costs as well as stakeholder management and perceived sustainability. Significant interaction effects were further analyzed by calculating simple slopes tests for high $(+1 S D)$ and low $(-1 S D)$ levels of the moderating variables (Cohen et al. 2003).

\subsection{Descriptive statistics and correlations}

Descriptive statistics and correlations over all scenarios can be found in Table 1.

\subsection{Hypotheses testing}

Regression results for participants' willingness to invest and for the amount of invested money can be found in Table 2 .

We started by testing Hypothesis 1, which stated that the assumed costs of managing non-shareholding stakeholders' interests moderate the relationship between stakeholder management and (potential) investors' investment intentions. Indeed, for participants' willingness to invest, there was a significant interaction effect between stakeholder management and assumed costs, $b=-0.37, S E=0.07$,

\footnotetext{
1 The three dummy variables for the scenarios were coded as follows: Dummy Airlines $_{\text {coded as }}$ $1=$ airlines, $0=$ not airlines; Dummy Employees $_{\text {coded }}$ as $1=$ employees, $0=$ not employees; Dummy Community $_{\text {coded as }} 1=$ community, $0=$ not community.
} 


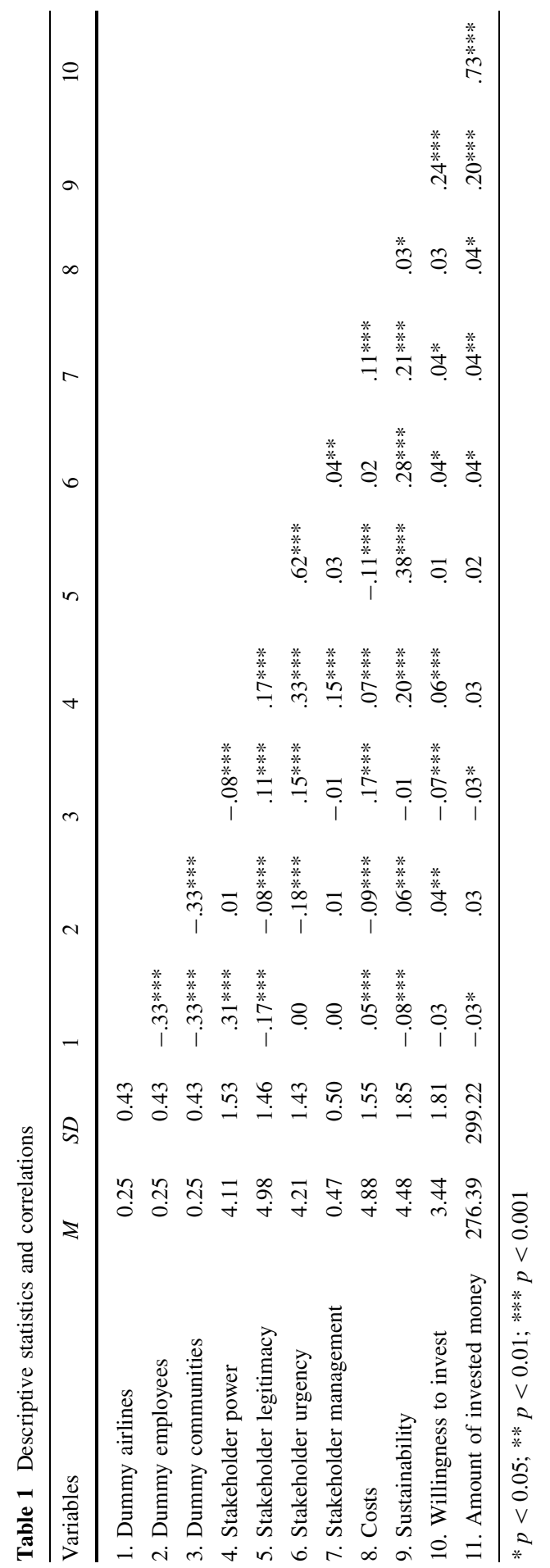




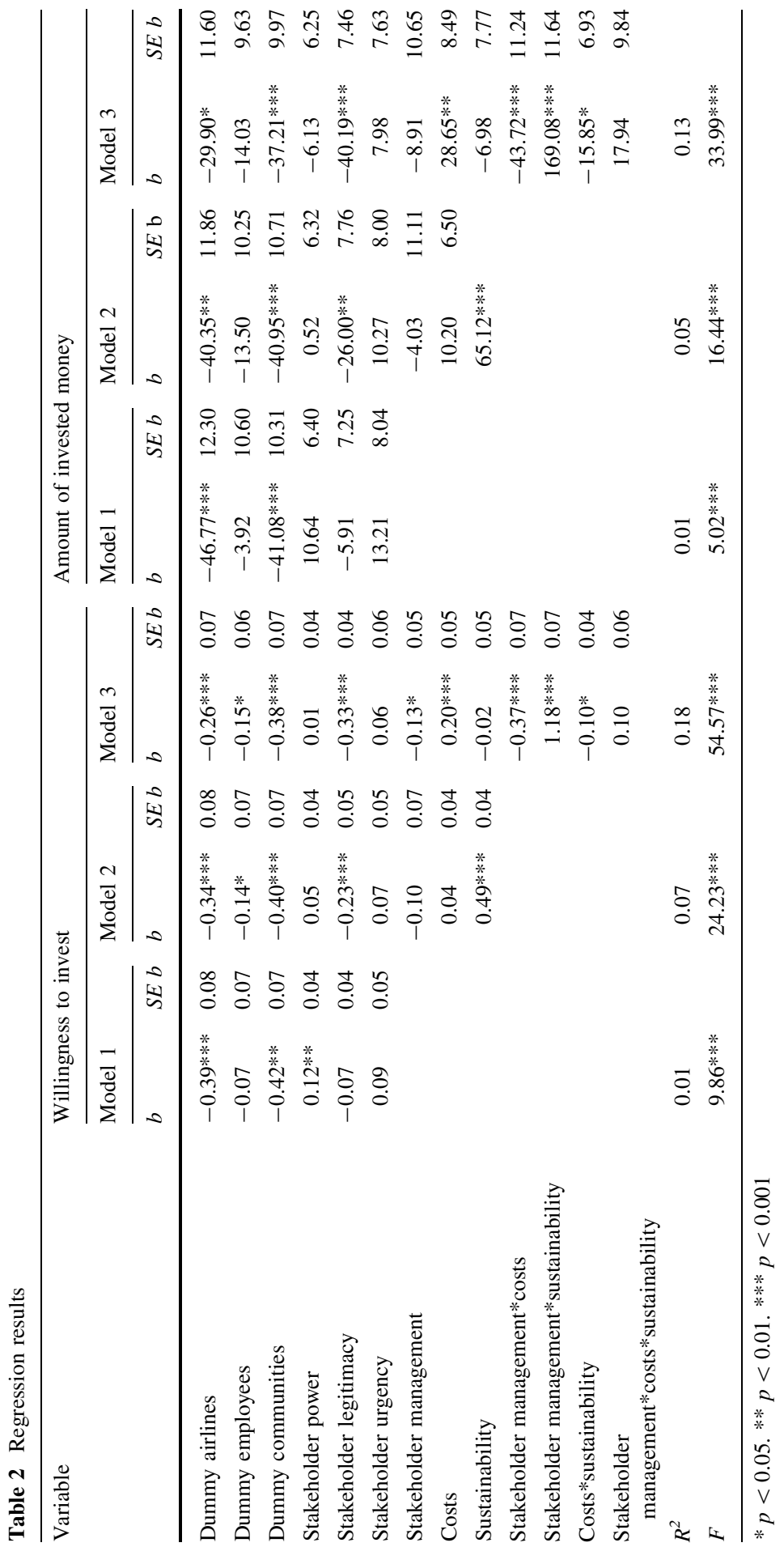


$t=-5.48, p<0.001 ; R^{2}=0.18, F(13,996)=54.57, p<0.001$ (see Fig. 1). The simple slopes test revealed that, for high assumed costs, participants were more willing to invest when the company prioritized shareholding over non-shareholding stakeholders, $b=-0.45, S E=0.10, t=-4.49, p<0.001$, while for low assumed costs, they were more willing to invest when the company prioritized nonshareholding over shareholding stakeholders, $b=0.62, S E=0.10, t=6.09$, $p<0.001$.

In addition, for participants' amount of invested money, there was a corresponding interaction effect between stakeholder management and assumed costs, $b=-43.72, S E=11.24, t=-3.89, p<0.001 ; R^{2}=0.13, F(13,996)=33.99$, $p<0.001$ (see Fig. 1). The simple slopes test revealed that, for high assumed costs, participants were willing to invest more money when the company prioritized shareholding over non-shareholding stakeholders, $b=-46.60, \quad S E=16.22$, $t=-2.87, p<0.01$, while for low assumed costs, they were willing to invest more money when the company prioritized non-shareholding over shareholding stakeholders, $b=87.72, S E=16.09, t=5.45, p<0.001$. Hypothesis 1 was thus confirmed both for participants' willingness to invest and for the amount of money they were willing to invest; in the case of high costs, participants' investment intentions were higher when the company preferred shareholding stakeholders, while in case of low costs, they were higher when the company preferred nonshareholding stakeholders.

We then tested Hypothesis 2, which stated that the perceived sustainability of managing non-shareholding stakeholders' interests moderates the relationship between stakeholder management and (potential) investors' investment intentions. For participants' willingness to invest, there was a significant interaction effect between stakeholder management and perceived sustainability, $b=1.18$, $S E=0.07, t=17.23, p<0.001 ; R^{2}=0.18, F(13,996)=54.57, p<0.001$ (see Fig. 2). The simple slopes test revealed that, for high perceived sustainability, participants were more willing to invest when the company prioritized nonshareholding over shareholding stakeholders, $b=1.04, S E=0.10, t=10.36$, $p<0.001$, while for low perceived sustainability, they were more willing to invest when the company prioritized shareholding over non-shareholding stakeholders, $b=-1.30, S E=0.09, t=-15.18, p<0.001$.

Analyzing participants' amount of invested money, there was also a significant interaction effect between stakeholder management and perceived sustainability, $b=169.08, S E=11.64, t=14.53, p<0.001 ; R^{2}=0.13, F(13,996)=33.99$, $p<0.001$ (see Fig. 2). The simple slopes test revealed that, for high perceived sustainability, participants were willing to invest more money when the company prioritized non-shareholding over shareholding stakeholders, $b=158.83$, $S E=15.80, t=10.05, p<0.001$, while for low perceived sustainability, they were willing to invest more money when the company prioritized shareholding over non-shareholding stakeholders, $b=-174.87, S E=14.88, t=-11.75, p<0.001$. Thus, Hypothesis 2 was confirmed both for participants' willingness to invest and for the amount of money they were willing to invest; in the case of high sustainability, investment intentions were higher when the company preferred non- 

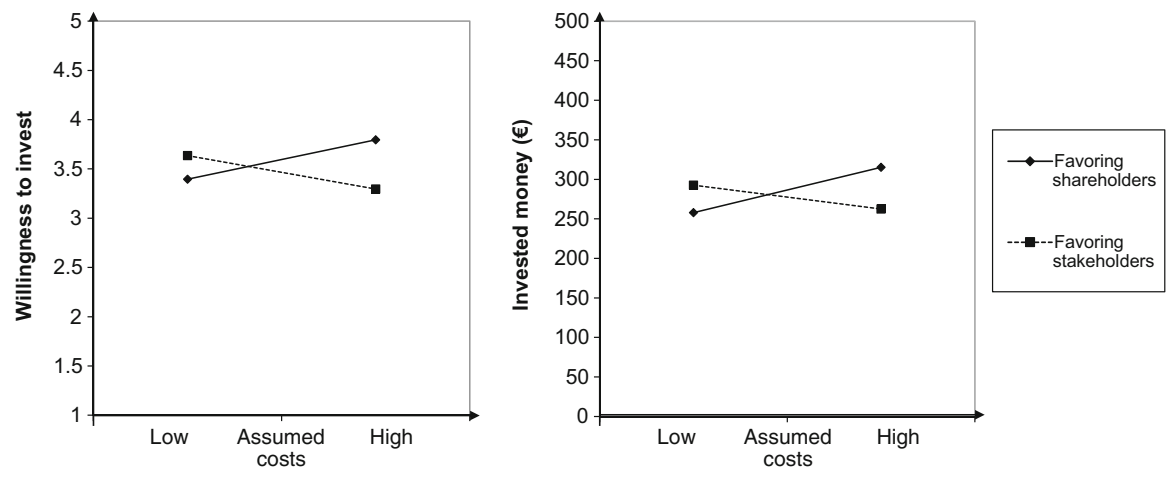

Fig. 1 Interaction effect of stakeholder management and assumed costs on participants' willingness to invest and amount of money invested
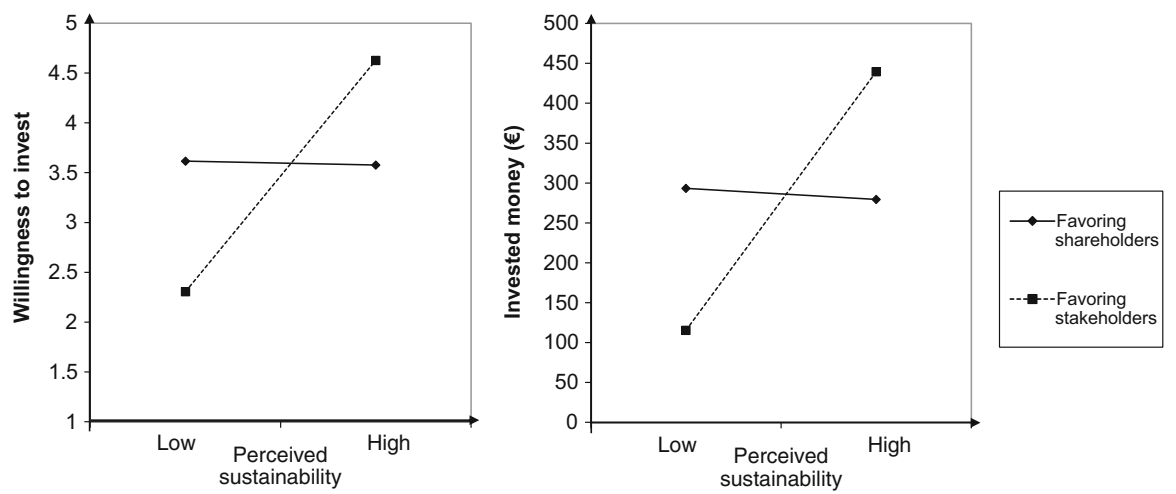

Fig. 2 Interaction effect of stakeholder management and perceived sustainability on participants' willingness to invest and amount of money invested

shareholding stakeholders, while in case of low sustainability, they were higher when the company preferred shareholding stakeholders.

\section{Discussion}

Our study was meant to shed light on how (potential) investors react to companies' management of shareholding and non-shareholding stakeholders. As expected, our results show that assumed costs and perceived sustainability indeed influence (potential) investors. Depending on these variables, investment behavior in response to companies' stakeholder management showed opposite patterns. For high assumed costs and low perceived sustainability, (potential) investors' investment intentions were more favorable when companies prioritized shareholding over non-shareholding stakeholders. In contrast, for low assumed costs and high perceived sustainability, (potential) investors were more willing to invest, and were likely to invest a 
higher amount of money, when companies decided to favor non-shareholding over shareholding stakeholders.

\subsection{Contributions to theory}

Overall, this paper contributes to our current understanding of investment decisions in several ways. First, it broadens stakeholder theory's focus by taking individual investors' reactions to corporate stakeholder management into account (Freeman 1984; Freeman et al. 2010). Our finding that (potential) investors attach importance to the financial sustainability of stakeholder management activities is especially valuable against the background of the "Enlightened Stakeholder Theory" (Jensen 2002), which argues that companies should make trade-offs between various stakeholder groups based on the principle of long-term firm value enhancement. According to this perspective, only those claims of non-shareholding stakeholders that will sustainably benefit corporate success should be fulfilled. Indeed, our data show that this approach is valuable because investors' reactions are likely to be positively influenced by fulfilling sustainable stakeholder claims. Going beyond Enlightened Stakeholder Theory, however, our findings also show that costs matter, with investors reacting more positively to the management of non-shareholding stakeholders when the costs necessary for it are assumed to be low. Considering investors' perspective thus offers a valuable addition to the largely manager-focused research conducted in this area so far (Friedman and Miles 2002).

Moreover, the results of our study indicate a means by which the opposing theoretical perspectives regarding (potential) investors' preference for prioritizing either shareholding or non-shareholding stakeholders can be reconciled (Jansson and Biel 2011; Rivoli 1995). The assumed costs and perceived sustainability reliably moderated the effect of stakeholder management on participants' willingness to invest, leading to directly opposing investment preferences when assumed costs were low and perceived sustainability was high versus when assumed costs were high and perceived sustainability was low.

With this finding, our paper also contributes to the general literature on individual investment behavior (Nagy and Obenberger 1994; Schijven and Hitt 2012) and investors' attitudes toward stakeholder management (Hofmann et al. 2008; Lotz and Fix 2014): Our paper is one of the first to consider stakeholder-related investment decisions on an individual investor level (Aguinis and Glavas 2012). By showing that high perceived sustainability and low costs of activities meant to manage nonshareholding stakeholders enhance investment in a company, our paper provides evidence that investors are driven by both short- and long-term financial goals (Jansson and Biel 2011; Wärneryd 2001) and that, similar to managers, they judge stakeholder management against the background of a financial time perspective (Crane et al. 2015). Moreover, our paper indicates that (potential) investors are unlikely to accept considerably lower financial gains only for the sake of addressing non-shareholding stakeholders' concerns (Lewis and Mackenzie 2000), but it also suggests that decisions in favor of shareholders will only increase their investment intentions when taking care of non-shareholding stakeholders' interests is seen as cost-intensive or unsustainable. 


\subsection{Contributions to practice}

By analyzing (potential) investors' reactions to the management of stakeholders' interests, this study offers meaningful implications for practice. First, it offers evidence-based advice for companies struggling with competing stakeholder claims. While stakeholder theory asks managers to balance the interests of their stakeholders (Freeman 1984; Jones and Felps 2013), it unfortunately gives little specific guidance on how to do so (Crane et al. 2015; Jensen 2002). Our results show that companies may use estimations about the costs and overall sustainability of stakeholder management activities when confronted with the decision of whether to yield to the claims of non-shareholding stakeholders or rather to give a higher dividend to shareholders. In such cases, those claims of non-shareholding stakeholders that come with low costs or high sustainability should be fulfilled, as this will also be seen in a favorable light by potential future investors. Accounting-based measures can be used to calculate potential future revenues and current costs by engaging in stakeholder management activities (Hall et al. 2015).

Second, our findings can help companies not only to decide which stakeholder claims to fulfill, but also to strategically adapt corporate communications about stakeholder management activities in general (Schwarzkopf 2006). Stressing the sustainability of managing non-shareholding stakeholders' interests for corporate success or the low costs associated with doing so might constitute a way in which alignment of different stakeholder groups' interests can be reached. For example, outlining in the annual report why and how taking care of certain non-shareholding stakeholders will benefit the company financially should enhance investors' acceptance of these measures and, in turn, positively affect their investment behavior. However, our results also highlight that companies might be well-advised to carefully handle communications in case they decide to prioritize the interests of their shareholders. Thus, it might also pay to use press releases to outline the fact that the costs of fulfilling non-shareholders' claims were too high, while the contribution to the organization's long-term success was too low to ensure acceptance. Hence, interestingly, organizations should not assume that decisions in favor of shareholding stakeholders will always be the investors' preferred option. In sum, adapting corporate communication might thus constitute an important measure to ensure (potential) investors' willingness to invest - a crucial prerequisite of stakeholder management's success (Hillenbrand et al. 2013).

\subsection{Limitations and opportunities for future research}

Despite this study's theoretical and practical contributions, it also has some limitations that provide fruitful opportunities for future research. First, we used scenario studies to test our hypotheses because they allow for analyzing the factors that drive individuals' investment decisions in a controlled setting (Ackert and Church 2006). This approach is common in studies examining factors that affect individual investors' decisionmaking (Barreda-Tarrazona et al. 2011; Clark-Murphy and Soutar 2004; Hofmann et al. 2008; Pasewark and Riley 2010; Schwarzkopf 2006). Moreover, it is important for enhancing clarity about the specific factors influencing individuals' investment decisions, as these have so far largely remained a "black box" (Schijven and Hitt 2012, 
p. 1250) due to the database methodologies predominantly employed in previous research. However, this approach also bears the disadvantage of being based on realistic but hypothetical investment decisions and of measuring investment intentions instead of actual investments. Future research might therefore benefit from repeating our results, for example, in an experimental simulation in which participants actually invest their own money or incur gains and losses through their investment decisions, or, alternatively, in a retrospective analysis of real company cases. Nevertheless, we are confident that our results apply to real-world settings, as scenario studies are generally characterized by a high degree of external validity (Aguinis and Bradley 2014), and intentions have been theorized and empirically proven to be the best predictors of subsequent behavior (Ajzen 1991; Sheeran 2002).

To reflect the competing stakeholder claims with which companies are frequently confronted in practice (Clarkson 1995; Mitchell et al. 2015), our scenarios implied a contrasting trade-off between shareholders and non-shareholding stakeholders, meaning that only one or the other of shareholders' or non-shareholding stakeholders' immediate interests were fulfilled. While this approach is valuable for mapping regularly occurring conflicts between shareholders and non-shareholding stakeholders (Donaldson and Preston 1995), it does not describe the full range of possible shareholder-stakeholder constellations, as shareholding and non-shareholding stakeholders' interests are not always directly at odds (Friedman and Miles 2002). It speaks to our results that, even though our scenarios were framed in a way that implied lower dividends for shareholders when non-shareholding stakeholders' claims were fulfilled, the investors examined did actually favor the prioritization of non-shareholding stakeholders in the event that the assumed costs of doing so were low and the perceived sustainability was high. Thus, while we believe that our design constitutes a conservative test of our hypotheses, replicating our results with a design in which different stakeholders' interests are not depicted as mutually exclusive would be a worthwhile endeavor for future research.

In our study, we focused on two potential moderating variables-assumed costs and perceived sustainability-which exerted a decisive effect on investors' reactions to stakeholder management activities. Yet, their effect may further be influenced by other variables. Investors might react differently to stakeholder management activities if they doubt that a certain stakeholder-related decision resulted from managers' volitional choice. Assuming for example external circumstances such as the absence of sufficient resources to explain managers' decision making might weaken potential negative reactions to refusing sustainable stakeholder requests. It would hence provide a valuable approach for further research to take this potential additional moderator into account.

Finally, we tested our hypotheses in a sample representative of German investors, which might restrain our findings' transferability to international contexts. Previous research has characterized continental investors (e.g., Germans) as being more strongly driven by long-term returns than Anglo-American ones (e.g., US citizens; Aguilera et al. 2007). Hence, it is possible that the perceived sustainability of managing non-shareholding stakeholders' claims plays less of a role for American investors. Including investors' cultural background as a potential moderator in the relationship between stakeholder management's perceived costs and sustainability 
on the one hand and investment decisions on the other could therefore provide an interesting avenue for future research.

\section{Conclusion}

As companies are still struggling to find the optimal way to manage shareholding and non-shareholding stakeholders' interests (Bird et al. 2007), our research shows that investors' preferences for prioritizing either the interests of shareholders or those of non-shareholding stakeholders crucially differ depending on the assumed costs and perceived sustainability associated with the decision. These findings broaden stakeholder theory's focus by taking individual investors' reactions to corporate stakeholder management into account. Providing evidence for and extending the "Enlightened Stakeholder Theory" (Jensen 2002), our results show that managers are well advised to highlight the fact that perceived sustainability is high and assumed costs are low when favoring non-shareholding stakeholders in their decisions, whereas they should highlight the low sustainability and high costs related to stakeholder management when favoring shareholders.

Acknowledgements Preparation of this article was funded by the German Federal Ministry of Education and Research and by the European Social Fund of the European Union (FKZ 01FP1072/73, research project "Selection and Assessment of Leaders in Academia and Business").

Open Access This article is distributed under the terms of the Creative Commons Attribution 4.0 International License (http://creativecommons.org/licenses/by/4.0/), which permits unrestricted use, distribution, and reproduction in any medium, provided you give appropriate credit to the original author(s) and the source, provide a link to the Creative Commons license, and indicate if changes were made.

\section{References}

Ackert, Lucy F., and Bryan K. Church. 2006. Firm image and individual investment decisions. The Journal of Behavioral Finance 7(3): 155-167. doi:10.1207/s15427579jpfm0703_4.

Adams, Renée B., Amir N. Licht, and Lilach Sagiv. 2011. Shareholders and stakeholders: How do directors decide? Strategic Management Journal 32(12): 1331-1355. doi:10.1002/smj.940.

Agle, Bradley R., Ronald K. Mitchell, and Jeffrey A. Sonnenfeld. 1999. Who matters to CEOs? An investigation of stakeholder attributes and salience, corporate performance, and CEO values. Academy of Management Journal 42(5): 507-525. doi:10.2307/256973.

Aguilera, Ruth V., Deborah E. Rupp, Cynthia A. Williams, and Jyoti Ganapathi. 2007. Putting the S back in corporate social responsibility: A multilevel theory of social change in organizations. Academy of Management Review 32(3): 836-863. doi:10.5465/AMR.2007.25275678.

Aguinis, Herman, and Kyle J. Bradley. 2014. Best practice recommendations for designing and implementing experimental vignette methodology studies. Organizational Research Methods 17(4): 351-371. doi:10.1177/1094428114547952.

Aguinis, Herman, and Ante Glavas. 2012. What we know and don't know about corporate social responsibility a review and research agenda. Journal of Management 38(4): 932-968. doi:10.1177/ 0149206311436079.

Ajzen, Icek. 1991. The theory of planned behavior. Organizational Behavior and Human Decision Processes 50(2): 179-211. doi:10.1016/0749-5978(91)90020-T. 
Barreda-Tarrazona, Iván, Juan C. Matallín-Sáez, and M. Rosario Balaguer-Franch. 2011. Measuring investors' socially responsible preferences in mutual funds. Journal of Business Ethics 103(2): 305-330. doi:10.1007/s10551-011-0868-z.

Benson, Bradley W., and Wallace N. Davidson. 2010. The relation between stakeholder management, firm value, and CEO compensation: A test of enlightened value maximization. Financial Management 39(3): 929-964. doi:10.1111/j.1755-053X.2010.01100.x.

Bird, Ron, Anthony D. Hall, Francesco Momentè, and Francesco Reggiani. 2007. What corporate social responsibility activities are valued by the market? Journal of Business Ethics 76(2): 189-206. doi:10.1007/s10551-006-9268-1.

Cameron, A.Colin, and Douglas L. Miller. 2011. Robust inference with clustered data. In Handbook of empirical economics and finance, ed. Aman Ullah, and David E. Giles, 1-28. Boca Raton: CRC Press.

Clark-Murphy, Marilyn, and Geoffrey N. Soutar. 2004. What individual investors value: Some Australian evidence. Journal of Economic Psychology 25(4): 539-555. doi:10.1016/S0167-4870(03)00056-4.

Clark-Murphy, Marilyn, and Geoffrey N. Soutar. 2005. Individual investor preferences: A segmentation analysis. The Journal of Behavioral Finance 6(1): 6-14. doi:10.1207/s15427579jpfm0601_2.

Clarkson, Max E. 1995. A stakeholder framework for analyzing and evaluating corporate social performance. Academy of Management Review 20(1): 92-117. doi:10.5465/AMR.1995. 9503271994.

Cohen, Jacob, Patricia Cohen, Stephen G. West, and Leona S. Aiken. 2003. Applied multiple regression/correlation analysis for the behavioral sciences. Mahwah, NJ: Erlbaum.

Coombs, Joseph E., and K. Matthew Gilley. 2005. Stakeholder management as a predictor of CEO compensation: Main effects and interactions with financial performance. Strategic Management Journal 26(9): 827-840. doi:10.1002/smj.476.

Crane, Andrew, Cameron Graham, and Darlene Himick. 2015. Financializing stakeholder claims. Journal of Management Studies 52(7): 878-906. doi:10.1111/joms.12147.

Donaldson, Thomas, and Lee E. Preston. 1995. The stakeholder theory of the corporation: Concepts, evidence, and implications. Academy of Management Review 20(1): 65-91. doi:10.5465/AMR.1995. 9503271992.

Faleye, Olubunmi, and Emery A. Trahan. 2011. Labor-friendly corporate practices: Is what is good for employees good for shareholders? Journal of Business Ethics 101(1): 1-27. doi:10.1007/s10551010-0705-9.

Freeman, R.Edward. 1984. Strategic management: A stakeholder approach. Boston: Pitman.

Freeman, R.Edward, Jeffrey S. Harrison, Andrew C. Wicks, Bidhan L. Parmar, and Simone De Colle. 2010. Stakeholder theory: The state of the art. Boston: Cambridge University Press.

Friedman, Milton. 1970. The social responsibility of business is to increase its profits. New York Times Magazine 13: 32-33.

Friedman, Andrew L., and Samantha Miles. 2002. Developing stakeholder theory. Journal of Management Studies 39(1): 1-21. doi:10.1111/1467-6486.00280.

Garcia-Castro, Roberto, Miguel A. Ariño, and Miguel A. Canela. 2010. Does social performance really lead to financial performance? Accounting for endogeneity. Journal of Business Ethics 92(1): 107-126. doi:10.1007/s10551-009-0143-8.

Hall, Matthew, Yuval Millo, and Emily Barman. 2015. Who and what really counts? Stakeholder prioritization and accounting for social value. Journal of Management Studies 52(7): 907-934. doi:10.1111/joms.12146.

Hillenbrand, Carola, Kevin Money, and Abby Ghobadian. 2013. Unpacking the mechanism by which corporate responsibility impacts stakeholder relationships. British Journal of Management 24(1): 127-146. doi:10.1111/j.1467-8551.2011.00794.x.

Hillman, Amy J., and Gerald D. Keim. 2001. Shareholder value, stakeholder management, and social issues: What's the bottom line? Strategic Management Journal 22(2): 125-139. doi:10.1002/10970266(200101)22:2<125:AID-SMJ150>3.0.CO;2-H.

Hofmann, Eva, Erik Hoelzl, and Erich Kirchler. 2008. A comparison of models describing the impact of moral decision making on investment decisions. Journal of Business Ethics 82(1): 171-187. doi:10. 1007/s10551-007-9570-6.

Jansson, Magnus, and Anders Biel. 2011. Motives to engage in sustainable investment: A comparison between institutional and private investors. Sustainable Development 19(2): 135-142. doi:10.1002/ sd.512. 
Jensen, Michael C. 2002. Value maximization, stakeholder theory, and the corporate objective function. Business Ethics Quarterly 12(2): 235-256. doi:10.1111/j.1745-6622.2001.tb00434.x.

Jones, Thomas M., and Will Felps. 2013. Stakeholder happiness enhancement: A neo-utilitarian objective for the modern corporation. Business Ethics Quarterly 23(3): 349-379. doi:10.5840/beq201323325.

Laplume, André O., Karan Sonpar, and Reginald A. Litz. 2008. Stakeholder theory: Reviewing a theory that moves us. Journal of Management 34(6): 1152-1189. doi:10.1177/0149206308324322.

Lewis, Alan, and Craig Mackenzie. 2000. Morals, money, ethical investing and economic psychology. Human Relations 53(2): 179-191. doi:10.1177/0018726700532001.

Lotz, Sebastian, and Andrea R. Fix. 2014. Financial returns versus moral concerns: Laypeople's willingness to engage in fair investments. Social Justice Research 27(4): 487-503. doi:10.1007/ s11211-014-0222-6.

MacGregor, Donald G., Paul Slovic, David Dreman, and Michael Berry. 2000. Imagery, affect, and financial judgment. The Journal of Psychology and Financial Markets 1(2): 104-110. doi:10.1207/ S15327760JPFM0102_2.

McWilliams, Abagail, and Donald Siegel. 2001. Corporate social responsibility: A theory of the firm perspective. Academy of Management Review 26(1): 117-127. doi:10.5465/AMR.2001.4011987.

Michelson, Grant, Nick Wailes, Sandra Van Der Laan, and Geoff Frost. 2004. Ethical investment processes and outcomes. Journal of Business Ethics 52(1): 1-10. doi:10.1023/B:BUSI.0000033103. 12560.be.

Mitchell, Ronald K., Bradley R. Agle, and Donna J. Wood. 1997. Toward a theory of stakeholder identification and salience: Defining the principle of who and what really counts. Academy of Management Review 22(4): 853-886. doi:10.5465/AMR.1997.9711022105.

Mitchell, Ronald K., Harry J. Van Buren, Michelle Greenwood, and R. Edward Freeman. 2015. Stakeholder inclusion and accounting for stakeholders. Journal of Management Studies 52(7): 851-877. doi:10.1111/joms.12151.

Nagy, Robert A., and Robert W. Obenberger. 1994. Factors influencing individual investor behavior. Financial Analysts Journal 50(4): 63-68. doi:10.2469/faj.v50.n4.63.

Ogden, Stuart, and Robert Watson. 1999. Corporate performance and stakeholder management: Balancing shareholder and customer interests in the UK privatized water industry. Academy of Management Journal 42(5): 526-538. doi:10.2307/256974.

Parent, Milena M., and David L. Deephouse. 2007. A case study of stakeholder identification and prioritization by managers. Journal of Business Ethics 75(1): 1-23. doi:10.1007/s10551-007-9533-y.

Pasewark, William R., and Mark E. Riley. 2010. It's a matter of principle: the role of personal values in investment decisions. Journal of Business Ethics 93(2): 237-253. doi:10.1007/s10551-009-0218-6.

Peifer, Jared L. 2014. Fund loyalty among socially responsible investors: The importance of the economic and ethical domains. Journal of Business Ethics 121(4): 635-649. doi:10.1007/s10551-013-1746-7.

Rivoli, Pietra. 1995. Ethical aspects of investor behavior. Journal of Business Ethics 14(4): 265-277. doi:10.1007/BF00871897.

Schijven, Mario, and Michael A. Hitt. 2012. The vicarious wisdom of crowds: Toward a behavioral perspective on investor reactions to acquisition announcements. Strategic Management Journal 33(11): 1247-1268. doi:10.1002/smj.1984.

Schwarzkopf, David L. 2006. Stakeholder perspectives and business risk perception. Journal of Business Ethics 64(4): 327-342. doi:10.1007/s10551-006-0002-9.

Sheeran, Paschal. 2002. Intention-behavior relations: A conceptual and empirical review. European Review of Social Psychology 12(1): 1-36. doi:10.1080/14792772143000003.

Statista. 2015. Aktienkultur in Deutschland - Statista-Dossier. https://de.statista.com/statistik/studie/id/ 29841/dokument/aktienkultur-in-deutschland-statista-dossier/. Accessed 23 July 2016.

Stevens, Robin, Nathalie Moray, Johan Bruneel, and Bart Clarysse. 2015. Attention allocation to multiple goals: The case of for-profit social enterprises. Strategic Management Journal 36(7): 1006-1016. doi:10.1002/smj.2265.

Unruh, Gregory, David Kiron, Nina Kruschwitz, Martin Reeves, Holger Rubel and Alexander Meyer zum Felde. 2016. Investing for a sustainable future. MIT Sloan Management Review 57(4):1-29.

Wärneryd, Karl Erik. 2001. Stock-market psychology: How people value and trade stocks. Cheltenham, UK: Edward Elgar.

Weber, Elke U., Ann-Renee Blais, and Nancy E. Betz. 2002. A domain-specific risk-attitude scale: Measuring risk perceptions and risk behaviors. Journal of Behavioral Decision Making 15: 263-290. doi:10.1002/bdm.414. 